\title{
Factors Affecting University Student's Attitudes toward E-Commerce: Case of Mu'tah University
}

\author{
Mamdouh T. AL Ziadat ${ }^{1}$, Malek M. AL-Majali ${ }^{1}$, Ayed M. Al Muala ${ }^{1} \&$ Khaldoon H. Khawaldeh $^{1}$ \\ ${ }^{1}$ Applied Science University, Jordan \\ Correspondence: Ayed M. Al Muala, Applied Science University, Jordan. E-mail: aied_muala@yahoo.com
}

Received: April 2, 2013

Accepted: May 27, 2013 Online Published: September 16, 2013

doi:10.5539/ijms.v5n5p88

URL: http://dx.doi.org/10.5539/ijms.v5n5p88

\begin{abstract}
Regardless of the widespread use of Internet in Jordan, according to e-commerce users, it is still notably low. The present study attempts to determine the success factors in improving users' attitude towards e-commerce in Jordan with the help of technology acceptance model (TAM). The research model comprises of four independent variables namely perceived usefulness, perceived ease of use, awareness and trust, and on dependent variable namely consumers' attitude towards e-commerce. Questionnaires numbering 100 are distributed among Mu'tah University graduate students and the response rate is a notable $100 \%$. The findings of the study show a significant and positive link between all four variables, and attitude toward e-commerce.
\end{abstract}

Keywords: TAM, e-commerce, Jordan

\section{Introduction}

Internet, in the current world, is considered not only a networking media but also a way to transact with consumers on a global level. The use of Internet has increased exponentially over the past years and it has become a mainstream tool in delivering and trading information, services and goods (Albarq, 2006). In the context of Jordan, the scenario is such that IT (information technology) is used as a new marketing tool. As such, the Jordanian consumer still has various reservations of purchasing through the Internet except those who use it as informative, entertainment and communication tool. Owing to the increasing growth of e-commerce, consumer purchase decisions are being conducted in environments described as computer-mediated (Nuseir \& Al-Masri, 2010). Although Internet penetration in Jordan was reported at $30 \%$ based on the Internet World Stats (2011), a mere $3 \%$ of the total users are e-commerce users including those who buy products and pay bills online (from Arabia Advisors Group Survey, 2011). The present study attempts to determine the success factors influencing Jordanian customers' attitudes towards e-commerce by first identifying the consumers' characteristics and then the factors affecting their attitude towards Internet.

\section{Literature Review}

The present study is underpinned by the technology acceptance model (TAM). In TAM, Davis brought forward two determinants namely perceived usefulness and perceived ease of use as depicted in Figure 1. Besides the present study, TAM has also set the baseline for significant number of researches in information and computer technology adoption and usage (Davis, 1989). Other researchers extended the TAM model to include additional variables that can be attributed to the many variances in computer technology usage (Abad, 2010). In the same way, in the present study the researcher adds new variables as min factors effecting Jordanian customers' attitude towards e-commerce. And owing to the fact that prior studies conducted in Jordan failed to determine the success factors of e-commerce adoption, the present study concentrates on customers' attitude toward e-commerce adoption as a key success factor. 


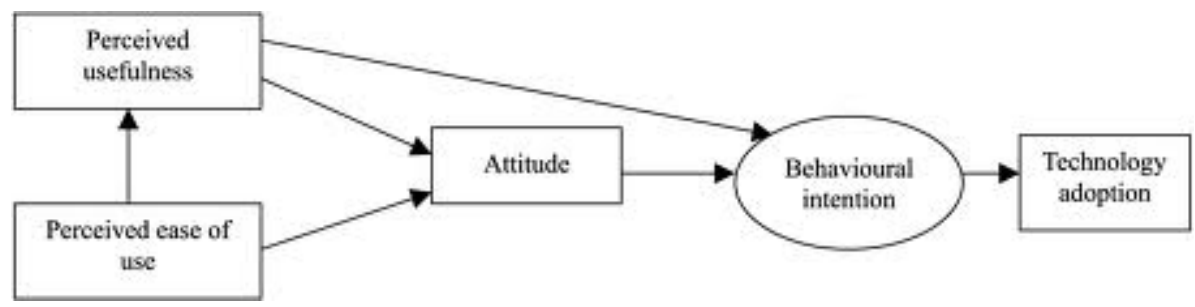

Figure 1. Technology Acceptance Model (TAM)

\section{Framework of Study}

Attitude: Online shopping attitudes are described as the psychological state of the consumers in light of purchasing online (Li \& Zang, 2002). The consumers' attitude towards online shopping is considered as the primary factor affecting e-shopping potential (Michael, 1998). The present study's model exhibits the relationship between independent variables comprising trust, awareness, perceived usefulness and perceived ease of use, and dependent variable comprising attitude toward E-commerce as depicted in Figure 2 below.

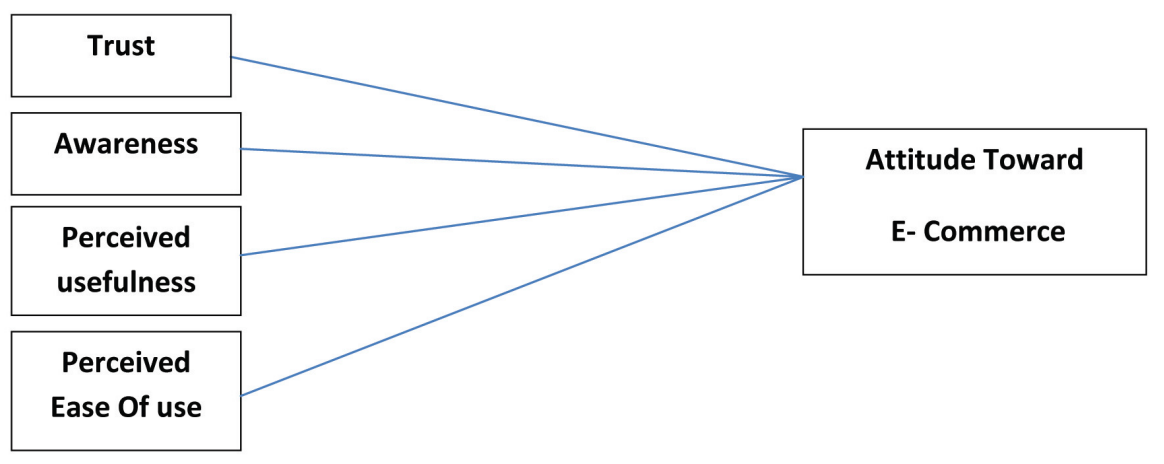

Figure 2. Model of study

Perceived usefulness is described as the prerequisite of mass market technology acceptance which hinges on the expectations of consumers regarding the way the use of technology can pave the way for improved and simplified lives (Peterson et al. 1997). Perceived benefits refer to advantageous outcome that stems from attributes and these benefits may be physiological, psychological or material in nature (Gutman, 1982). In the context of online shopping, consumer perceived benefits are described as the aggregate advantages or satisfactions of online shopping that meet the needs or wants of consumers (Shwu-Ing, 2003). As such, extrinsic advantages are features of wide array of product selection, competitive pricing, easy access to information and low search costs (Delafrooz \& Khatibi, 2009). Prior literature revealed that the strongest linear relationship lies between attitude toward online shopping and perceived benefits of online shopping (Delafrooz \& Khatibi, 2009). Therefore, the present study postulates the following positive hypothesis;

\section{H1: Perceived usefulness has significant and positive influence on consumers' attitude toward e-commerce.}

Perceived Ease of use is defined as the level to which an individual is convinced that using a certain system would be free from effort. This stems from the definition of ease which is the freedom from difficulty or significant effort. Effort is described as a finite resource that an individual can exert to the many activities for which he or she is responsible to conduct (Radner \& Rothschild, 1975). Ease of use encapsulates the features of time saving, site design, site navigation, information architecture, site speed, and payment process, accessibility and search facilities (Constantinides, 2004; Wolfinbarger \& Gilly, 2001; Szymanski \& Hise, 2000). In Delfrooz \& Khatibi's (2009) study, ease of use was revealed to significantly and positively relate with attitude toward online shopping and thus in the present study, a positive linkage is also hypothesized;

\section{H2: Perceived ease of use has significant and positive influence on consumers' attitude toward e-commerce.}

Awareness refers to the familiarization of consumers through advertising and marketing of the company brand, product and services, and making consumers aware of the special features and benefits of such products and 
services and the way it is distinct from competitive brands in function or style. In addition, consumers who receive information through mass media or word of mouth will be aware of the products and services (Asseal, 1995). In other words, promotion is significant in creating awareness towards the online services (Anita, Noor \& Abdul Manap, 2012). Some prior studies revealed consumer purchase decisions to be related to e-promotions (Nuseir \& Al-Masri, 2010) while others revealed that site awareness significantly affects consumer's site commitment (Chung-Hoon Park \& Young-Gul Kim, 2003). Therefore, the present study hypothesizes the following positive relationship:

H3: Awareness of existence of e-commerce has significant and positive influence on consumers' attitude toward e-commerce.

Trust among the most significant barriers to people's engagement in e-commerce is lack of trust as such transactions require the submission of financial and personal information to be submitted to the sellers over the Internet. Because of lack of trust the e-commerce future is tenuous. This puts the emphasis on building consumer trust on the Internet for online merchants - a topic of increasing interest and importance in the field of research (Wang \& Emurian, 2004). Moreover, some prior studies (e.g. Younes \& Talal, 2011; Nuseir, 2010; Park \& Kim, 2003; Wang \& Emurian, 2004) revealed a significant positive relationship while others found an insignificant one (Gurvinder \& Zhaobin, 2005). Therefore, the present study postulates the following hypothesis;

\section{H4: Trust has significant and positive influence on consumers'attitude toward e-commerce.}

\section{Methodology}

The study mainly employed the quantitative approach to research with the units of analysis as graduate students studying in Mu'tah University.

\subsection{Measurement}

The study questionnaire was designed to contain three parts; the cover letter explaining the study title and the justification behind it as well as the purpose of the questionnaire, the sample study's demographic profile, and the four latent constructs hypothesized to influence consumers' attitude towards e-commerce in Jordan which comprises of 22 items. The constructs were adopted from prior studies found in literature with awareness measured by four times (adopted from Al-Somali, Gholami, \& Clegg, 2009); trust measured by seven items (six from Suh \& Han, 2002; and one added by the researcher); perceived ease of use and perceived usefulness by ten items (adopted from Davis, 1989); and finally, attitude by five items (adopted from Shih \& Fang, 2004). All items are measured through a seven point Likert scale with the following anchors; (1) strongly disagree to (7) strongly agree.

\subsection{Sample of Study}

For the purpose of studying the success factors that could influence consumers' attitude towards e-commerce in Jordan, the study sample was selected at random from registration department in Mu'tah University based on their registration numbers. Their selection is justified by the fact that they represent the highly educated sector of the society and they have easy access to the Internet and may have had experience in using e-commerce. The researcher distributed 100 questionnaires among the study sample and received a $100 \%$ response rate from them. These responses are then used in further analysis.

\subsection{Data Screening}

The dataset totaling 100 are then coded and entered into SPSS version 15 after which statistical analysis is conducted in three phases. First, factor analysis is conducted using varimax rotation method to extract constructs and determine the variance explained. The researcher adopted 0.5 as threshold of primary loading. The factor analysis results showed four constructs with factor loadings ranging from 0.504 to 0.838 . In addition, the questionnaire reliability is tested through computing coefficient alpha. Table 1 contains the results of Cronbach alpha reliability for the constructs which ranged from 0.87 to 0.93 , confirming the reliability of items that measure the underlying constructs as they exceed the acceptable level of reliability $(\alpha \geq 0.70)$ (Sekaran, 2003).

The second step involved the multicollinearity check of variables through the identification of correlations (whether they are equal to or greater than 0.70 ). The final step involved the regression test of hypotheses. Pearson's Correlation Analysis is conducted for this purpose to determine the strength and direction of the relationship between variables (Table 2). The correlation coefficients (r) values are provided in the table below and they show the strength and relationship among variables. 
Table 1. Alpha Cronbach

\begin{tabular}{lllll}
\hline Variable & $\begin{array}{l}\text { Perceived } \\
\text { Usefulness }\end{array}$ & $\begin{array}{l}\text { Perceived } \\
\text { Ease of use }\end{array}$ & Awareness & Trust \\
\hline Reliability Value & .91 & .88 & .93 & .87 \\
\hline
\end{tabular}

Table 2. Correlations between variables

\begin{tabular}{llllll}
\hline Factor & Attitude & $\begin{array}{l}\text { Perceived } \\
\text { Usefulness }\end{array}$ & $\begin{array}{l}\text { Perceived Ease } \\
\text { of Use }\end{array}$ & Awareness & Trust \\
\hline Attitude & 1 & & & & \\
Perceived Usefulness & .56 & 1 & & & \\
Perceived Ease of Use & .59 & .76 & 1 & 1 & \\
Awareness & .52 & .59 & .52 & .58 & 1 \\
Trust & .61 & .63 & .78 & \\
\hline
\end{tabular}

\section{Study Findings}

\subsection{Profile of Respondents}

Majority of the respondents' (74\%) ages were from $20-30$ years old, $21 \%$ from $31-40,4 \%$ from $41-50$ and $1 \%$ was over 50 years of age. The sample comprises of $58 \%$ of men and $42 \%$ of women with $63 \%$ of them unmarried and the remaining 37\% married. Majority of them (51\%) hail from villages while $49 \%$ come from cities. With regards to their education level, $72 \%$ of the respondents were pursuing master degrees and the remaining (28\%) were pursuing $\mathrm{PhD}$ degrees. Most of them were earning than $500 \mathrm{JD}(71 \%)$, while the other $22 \%$ were earning between 501-1000 JD, 2\% between 1001-1500 JD, and 5\% were earning over $1501 \mathrm{JD}$. As for the respondents Internet use, $42 \%$ of them have been using the Internet for $1-5$ years, $27 \%$ for $6-10$ years, $17 \%$ for less than a year, and finally $14 \%$ for over 10 years. Quite a significant number of respondents $(36 \%)$ were well-informed about e-commerce through the Internet, $15 \%$ were informed by family members, $15 \%$ were informed by friends, $11 \%$ from the TV, and $6 \%$ from newspapers. The remaining $17 \%$ were not aware of e-commerce. Majority of respondents access Internet from home (73\%), while $22 \%$ from their offices, and the remaining 5\% from the Internet cafes. The Internet is used by the respondents for academic purposes $(53 \%)$, for entertainment (23\%), for communication with friends $(20 \%)$, for investment (1\%), for product searching (19\%), for comparing product prices (17\%), for booking hotels and airline tickets online (12\%), for payment of bills $(10 \%)$, for e-banking $(5 \%)$ and for buying products online $(4 \%)$.

\subsection{Hypothesis Findings}

Through the use of simple regression, the hypothesis findings were revealed as presented in Table 3 . The findings show that perceived usefulness, perceived ease of use, awareness and trust positively affect attitude toward e-commerce (Table 3). The revised study model generated regression standardized estimates of the direct effects readings (Beta, $\mathrm{t}$-vale and $\mathrm{p}$-value) as depicted in Table 3. The hypotheses support that all direct paths are significant and positive ( $\mathrm{t}$-values $>+/-1.96$; $\mathrm{p}$-value $<0.05$ ).

Table 3. Hypothesis results

\begin{tabular}{|c|c|c|c|c|c|}
\hline Hypothesis & From & $\mathrm{t}$ & $\beta$ & $\mathrm{p}$-value & $\begin{array}{l}\text { Hypothesis } \\
\text { Support }\end{array}$ \\
\hline $\mathrm{H} 1$ & Usefulness $\longrightarrow$ Attitude & 7.70 & .614 & .000 & Yes \\
\hline $\mathrm{H} 2$ & ease of use $\longrightarrow$ Attitude & 7.15 & 586 & .000 & Yes \\
\hline $\mathrm{H} 3$ & awareness $\longrightarrow$ Attitude & 6.74 & .563 & .000 & Yes \\
\hline H4 & trust $\longrightarrow$ Attitude & 6.88 & .589 & .000 & Yes \\
\hline
\end{tabular}

\section{Discussion}

The current study is an attempt to empirically investigate the success factors that could influence consumers' attitude toward e-commerce in the context of Jordan with the help of the technology acceptance model (TAM). The finding showed perceived usefulness to have a significant positive influence on consumers' attitude. Additionally, a large standardized coefficient compared to its counterparts indicates the variable's large 
contribution in influencing consumers' attitude toward e-commerce. This shows that consumers are not aware of the e-commerce advantages. Similarly, perceived ease of use was found to significantly influence consumers' attitude toward e-commerce indicating that the companies should make e-commerce easy to use. Moreover, awareness, another success factor, was found to significantly influence consumers' attitude towards e-commerce and these calls for additional attempts to bring the benefits of e-commerce to consumers' awareness as evidence shows that $17 \%$ of graduate students are not even aware of e-commerce. Furthermore, trust also positively and significantly influences the attitude of consumers but the findings indicate that trust is a less important success factor when compared to other factors. This shows that Jordanian consumers trust e-commerce although more efforts need to be expended to develop trust through security development of online businesses which may decrease the risk and danger attached to e-commerce.

\section{Conclusion}

The present study aims to determine the factors that influence consumers' attitude toward e-commerce in Jordan through the employment of the technology acceptance model (TAM). The four variables (perceived usefulness, perceived ease of use, awareness and trust) were revealed to significantly impact consumer's attitude, which could be the main success factors for Jordanian e-commerce adoption. Future studies can investigate other factors like trialibility, compatibility and government support. Moreover, the present study can be applied to a large sample in various areas. Additionally, can examine this model in a different environment in three regions of Jordan, as is the case in the central region or the northern region, and can measure and investigate the attitudes of customers in more than one country as Kuwait, Saudi Arabia and other Arab countries.

\section{Acknowledgements}

The authors are grateful to the Applied Science University, Amman, Jordan, for the financial support granted to this research project (Grant No: 251/ع ب/19-5-2013)

\section{References}

Abad, M., Itxaso, D., \& Markel, V. (2010). Acceptance of Mobile Technology in Hedonic Scenarios. Retrieved from http://ewic.bcs.org/upload/pdf/ewic_hci10_paper28.pdf

Alamro, S., \& Tarawneh, S. A. (2011). Factors Affecting E-Commerce Adoption in Jordanian SMEs. European Journal of Scientific Research, 64(4).

Albarq. (2006). Intention to Shop Online Among University Students in Jordan. Universiti Utara Malaysia.

Al-Kasasbeh, M. M., Dasgupta, S., \& AL-Faouri, A. H. (2011). Factors Affecting E-Service Satisfaction.

Al-majali, M. (2011). Modeling the antecedents of internet banking service adoption (IBSA) in Jordan. Journal of internet banking and commerce, 16(2).

Al-Otaibi, M. B., \& Al-Zahrani, R. M. (2011). Electronic Commerce in the Kingdom of Saudi Arabia. College of Computer and Information Sciences, King Saud University.

Al-Somali, S. A., Gholami, R., \& Clegg, B. (2009). An investigation into the acceptance of online banking in Saudi Arabia. Technovation, 29(2), 130-141. http://dx.doi.org/10.1016/j.technovation.2008.07.004

Arab advisors group. (2011). Survey about e-commerce in Jordan. Retrieved from http://www.arabadvisors.com/

Asseal, H. (1995). Consumer behavior and marketing action. Cincination: Southwestern.

Chung-Hoon, P., \& Young-Gul, K. (2003). Identifying key factors affecting consumer purchase behavior in an online shopping context. International Journal of Retail \& Distribution Management, 31(3).

Constantinides, E. (2004). Influencing the online consumer's behavior: the Web experience. Internet Research, 14(2), 111-126. http://dx.doi.org/10.1108/10662240410530835

Delafrooz, L. H., Paim, H, S. M., \& Khatibi, A. (2009). Factors affecting students' attitude toward online shopping. African Journal of Business Management, 3(5).

Fred, D. D. (1989). Perceived Usefulness, Perceived Ease of Use, and User Acceptance of Information Technology. MIS Quarterly, 13(3), 319-340. http://dx.doi.org/10.2307/249008

Gurvinder, S. S., \& Chen, Z. (2005). Web-based shopping: consumers' attitudes towards online shopping in new zealand. Journal of Electronic Commerce Research, 6(2).

Gutman, J. (1982). A means-end chain model based on consumer categorization Processes. J. Marketing, 46, 60-72. http://dx.doi.org/10.2307/3203341 
Internet World Stats. (2011). Usage and population statistics. Retrieved from $\mathrm{http}: / / \mathrm{www}$.internetworldstats.com/middle.htm

Li, N., \& Zhang, P. (2002). Consumer online Shopping Attitudes and Behavior: An Assessment of research. Eighth Americas Conference on Information System.

Mahmud, A. K., \& Kumar, R. (2011). Investigating Uncertainty Avoidance and Perceived Risk for Impacting Internet Buying: A Study in Three National Cultures. International Journal of Business and Management, $6(5)$.

Michieal, K. (1998). E-shock the electronic shopping revolution: Strategies for retailers and manufactures. London, Mac Millan Business.

Norudin, M., Anita, M. S., \& Noor, R. A. M. (2012). Determinants of Awareness on Islamic Financial Institution E-Banking among Malaysian SMEs. International Journal of Business and Social Science, 3(5).

Nuseir, M., Nitin, A., \& Morad, A. (2010). Evidence of Online Shopping Determinants: A Jordanian Consumer Decision Process Perspective. International Review of Business Research Papers, 1(5).

Peterson, R. A., Balasubramanian, S., \& Bronnenberg, B. J. (1997). Exploring the implications of the Internet for consumer marketing. Journal of the Academy of Marketing Science, 25(4), 329-346. http://dx.doi.org/10.1177/0092070397254005

Radner, R., \& Rothschild, M. (1975). On the Allocation of Effort. Journal of Economic Theory, 358-376. http://dx.doi.org/10.1016/0022-0531(75)90006-X

Sekaran, U. (2003). Research methods for business: A skill-building approach (4th ed.). John Wiley \& Sons, Inc.

Shih, Y., \& Fang, K. (2004). The use of a decomposed theory of planned behavior to study Internet banking in Taiwan. Internet Research, 14(3), 213-223. http://dx.doi.org/10.1108/10662240410542643

Shwu-Ing, W. (2003). The relationship between consumer characteristics and attitude toward online shopping. Manag. Intelligence Planning, 21(1), 37-44. http://dx.doi.org/10.1108/02634500310458135

Suh, B., \& Han, I. (2002). Effect of trust on customer acceptance of Internet banking. Electronic Commerce Research and Applications, 1(3-4), 247-263. http://dx.doi.org/10.1016/S1567-4223(02)00017-0

Szymanski, D. M., \& Hise, R. T. (2000). E-satisfaction: an initial examination. Journal of Retailing, 76(3), 309-322. http://dx.doi.org/10.1016/S0022-4359(00)00035-X

Wang, Y. D., \& Emurian, H. H. (2005). An overview of online trust: Concepts, elements, and implications. Computers in Human Behavior, 21, 105-125. http://dx.doi.org/10.1016/j.chb.2003.11.008

Wolfinbarger, M., \& Gilly, M. (2001). Shopping online for freedom, control and fun. California Management Review, 43(2), 34-55. http://dx.doi.org/10.2307/41166074

Younes, A. A., \& Talal. (2011). E-Shopping: Spending and Behavioral Differences among Jordanian Youth's: Empirical Study. European Journal of Economics, Finance and Administrative Sciences, 28.

\section{Copyrights}

Copyright for this article is retained by the author(s), with first publication rights granted to the journal.

This is an open-access article distributed under the terms and conditions of the Creative Commons Attribution license (http://creativecommons.org/licenses/by/3.0/). 